E-JURNAL EKONOMI DAN BISNIS UNIVERSITAS UDAYANA
Available online at https://ojs.unud.ac.id/index.php/EEB/index
Vol. 10 No. 09, September 2021, pages: 777- 788
e-ISSN: 2337-3067

\title{
PENGARUH PERSEPSI KEGUNAAN, PENGARUH SOSIAL DAN KEBIASAAN TERHADAP NIAT BERALIH PADA PENGGUNA DOMPET DIGITAL
}

\section{Erika Rahma Kusuma Dewi ${ }^{1}$ Yessy Artanti $^{2}$}

\begin{tabular}{l} 
Article history: \\
\hline Submitted: 6 Mei 2021 \\
Revised: 26 Mei 2021 \\
Accepted: 3 Juni 2021
\end{tabular}

\section{Keywords:}

Perceived Usefulness;

Social Influence;

Habit;

Switching Intention;

\section{Kata Kunci:}

Persepsi Kegunaan;

Pengaruh Sosial;

Kebiasaan;

Niat Beralih;

\section{Koresponding:}

Fakultas Ekonomika dan

Bisnis, Universitas Negeri

Surabaya, Jawa Timur,

Indonesia

Email:

erika.17080574099@mhs.unes a.ac.id ${ }^{l}$
Abstract

As technology evolves, the use of e-wallet is increasing in Indonesia. However, the increasing use of e-wallet indicates uncertain consumer behavior in the choice of e-wallet brands. OVO is the e-wallet with the largest users in Indonesia in 2019. Meanwhile in 2020 the digital wallet with the largest user in Indonesia is ShopeePay. This study aims to analyze the effects of perceived usefulness, social influence, and habit on switching intention OVO users to ShopeePay. This research uses non probability sampling and judgemental sampling with characteristic of respondents were OVO users, are looking for information about ShopeePay with an age range of 20-40 years as many 200 respondents. Data collection was carried out by distributing online questionnaires. Data analysis teqniques using multiple linear regression. The results of this study examined while perceived usefulness, social influence, and habit had significant effects on switching intention

Abstrak
Semakin berkembangnya teknologi, penggunaan dompet digital
semakin meningkat di Indonesia. Akan tetapi, penggunaan dompet digital
yang meningkat menunjukkan perilaku tidak menentu dalam pemilihan
merek dompet digital. OVO merupakan dompet digital dengan pengguna
terbesar di Indonesia pada tahun 2019. Sedangkan pada tahun 2020 dompet
digital dengan pengguna terbesar di Indonesia yaitu ShopeePay. Penelitian
ini bertujuan untuk menganalisis pengaruh persepsi kegunaan, pengaruh
sosial, dan kebiasaan terhadap niat beralih pada pengguna OVO ke
ShopeePay. Penelitian ini menggunakan non probability sampling dengan
judgemental sampling. Responden adalah pengguna OVO yang sedang
mencari informasi mengenai ShopeePay dengan rentan usia 20-40 tahun
sebanyak 200 responden. Teknik analisis data menggunakan regresi linear
berganda. Hasil penelitian ini menunjukkan bahwa persepsi kegunaan,
pengaruh sosial, dan kebiasaan berpengaruh signifikan terhadap niat beralih

Fakultas Ekonomika dan Bisnis, Universitas Negeri Surabaya, Jawa Timur, Indonesia ${ }^{2}$

Email: yessyartanti@unesa.ac.id ${ }^{2}$ 


\section{PENDAHULUAN}

Kehidupan yang serba cepat telah menjadi gaya hidup masyarakat termasuk dalam penggunaan alat pembayaran yang mulai bergeser menggunakan pembayaran non tunai. Alat pembayaran non tunai terdiri dari paper based, paperless, card based dan prepaid product yang berbasis chip dan berbasis server seperti dompet digital. Berdasarkan riset yang dilakukan oleh Katadata Insight Center (KIC) menunjukkan bahwa penggunaan dompet digital untuk bertransaksi lebih besar dengan $11,1 \%$ dari responden dibandingkan dengan penggunaan $e$-money sebesar $9,1 \%$ (katadata.com, 2020). Kemudahan dalam penggunaan dan terjaminnya keamanan dalam pengggunaan dompet digital menyebabkan penggunaannya meningkat, karena transaksi dengan dompet digital dapat dilakukan ketika ponsel dalam keadaan hidup dan terkoneksi dengan jaringan internet. Selanjutnya data yang ditujukkan pada iprice.co.id tahun 2020 menunjukkan metode pembayaran masyarakat saat belanja online paling besar menggunakan transfer bank sebesar 30\% dan dompet digital sebesar $26 \%$ (iprice.co.id, 2020). Dalam penggunaan dompet digital diketahui generasi millnial merupakan pengguna terbanyak. Hal ini dibuktikan berdasarkan hasil survey oleh Research Director Experience Ipsos Indonesia generasi millennial merupakan pengguna dompet digital terbanyak sebesar $68 \%$ (Kompas.com, 2020).

Data dari Bank Indonesia menunjukkan terdapat 38 dompet digital yang telah memiliki lisensi di Indonesia. Perusahaan dompet digital saling mengembangkan fitur yang menawarkan kemudahan, manfaat yang didapatkan pengguna dan promo yang menarik. Dari banyaknya brand dompet digital di Indonesia, pada tahun 2019 tercatat bahwa dompet digital dengan pengguna terbanyak yaitu OVO sebesar $73 \%$ dan ShopeePay sebesar 31\% (wartaekonomi.com, 2019). Selanjutnya pada bulan Januari tahun 2020 survei oleh Warta Ekonomi menunjukkan jumlah pengguna OVO sebesar 90\% dan ShopeePay sebesar 54\% (wartaekonomi.com, 2020). Sedangkan survei yang dilakukan oleh Warta Ekonomi pada bulan Juni-Agustus 2020 menunjukkan perubahan jumlah pengguna brand dompet digital di Indonesia adalah ShopeePay sebesar 68\% dan OVO sebesar $56 \%$ (wartaekonomi.com, 2020).

Beragamnya perusahaan dompet digital dengan perbedaan fitur dan kelebihan yang ditawarkan, membuat konsumen sedikit banyak memiliki keinginan untuk beralih. Menurut Keaveney (1995), perilaku beralih konsumen terjadi ketika konsumen meninggalkan produk atau layanan lama kemudian menggantikan produk atau layanan yang baru. Sedangkan pada pengguna jasa, diperlukan pertimbangan ketika akan tetap menggunakan layanan jasa saat ini atau beralih ke layanan jasa lain yang serupa. Menurut (Rumengan, 2015), niat beralih merupakan kepastian atau kemungkinan konsumen akan beralih dari penggunaan layanan di perusahaan saat ini ke perusahaan lain. Selanjutnya Bansal et al., (2005) menjelaskan bahwa niat beralih merupakan tingkat kemungkinan konsumen akan berpindah dari perusahaan saat ini ke perusahaan yang lain. Kemudian menurut Jezy \& Papalapu, (2015) mendefinisikan niat beralih sebagai perilaku konsumen yang memiliki kecenderungan untuk beralih ke merek lain karena merek yang digunakan saat ini tidak memenuhi keinginan dan kebutuhan konsumen sehingga konsumen mencari informasi untuk menemukan merek yang mampu menyediakan kebutuhannya. Kecenderungan konsumen untuk berpindah dari perusahaan saat ini ke perusahaan lain disebut niat beralih.

Niat beralih pada penggunaan produk teknologi dipengaruhi oleh faktor psikologis, faktor sosial, motivasi teknologi, dan hambatan untuk beralih. Salah satu yang mempengaruhi niat beralih konsumen adalah persepsi kegunaan (Ahmed, 2017). Persepsi kegunaan adalah tingkat kepercayaan seseorang dengan menggunakan teknologi tertentu akan membuat pekerjaan menjadi lebih efektif. (Fahmi, et al.,, 2018). Selanjutnya, menurut Ahmed, (2017), persepsi kegunaan merupakan

Pengaruh Persepsi Kegunaan, Pengaruh Sosial dan Kebiasaan Terhadap Niat Beralih Pada Pengguna Dompet Digital, 
kemungkinan yang dirasakan konsumen bahwa ketika dengan memanfaatkan teknologi dapat memberikan keuntungan bagi pekerjannya. Sedangkan menurut menurut Chang, (2017) mendeifinisikan persepsi kegunaan adalah tingkat kepercayaan konsumen bahwa dengan penggunaaan teknologi tertentu dapat membuat pekerjaan mereka akan lebih efektif. Terdapat 4 dimensi persepsi kegunaan diantaranya penggunaan sistem mampu membuat pekerjaan menjadi lebih mudah, dapat menambah tingkat kinerja individu, meningkatkan produktivitas, dan berguna bagi penggunanya (Sun \& Zhang, 2006).

Salah satu hal yang mempengaruhi konsumen sadar akan informasi produk dan brand tertentu dipengaruhi oleh pengaruh sosial. Pengaruh sosial mencerminkan pengaruh pendapat orang lain penting terhadap persepsi individu dalam menggunakan produk atau jasa. Saat teman, rekan kerja, atau pemimpin menggunakan suatu produk dan merekomendasikannya untuk beralih ke produk tersebut. Menurut Wang \& Chou (2014), pengaruh sosial mengacu terhadap keputusan sesorang termasuk beralih ke produk atau layanan lain. Social influence atau pengaruh sosial merupakan seberapa besar lingkungan sosial berpengaruh terhadap perilaku orang lain melalui pendapat dan rekomendasi, sehingga dapat mempengaruhi dalam pengambilan keputusan (Wang \& Chou, 2014). Menurut Zhou (2018), mendefinisikan pengaruh sosial merupakan persepsi individu bahwa orang lain dapat mempengaruhi dalam keputusan menggunakan teknologi yang didasari pada norma subjektif dan citra sosial sehingga seseorang dianggap cenderung memperoleh perilaku yang diterima oleh rekan sosialnya. Sedangkan menurut Syah et al., (2018) pengaruh sosial adalah sejauh mana seseorang menganggap faktor lingkungan sosial di sekitarnya merupakan hal yang penting dan dapat mempengaruhi mereka untuk menggunakan teknologi. Pengaruh sosial dipengaruhi oleh dua dimensi yaitu subjective norm dan visibility dimana pada subjective norm memiliki indikator bagaimana kepercayaan seseorang dalam menyikapi hal tertentu dan kepercayaan seseorang dalam melakukan hal tertentu. Sedangkan pada visiability terdapat dua indikator yaitu perilaku konsumen lain yang mempengaruhi keputusan seseorang dan pengaruh lingkungan yang diamati konsumen dalam menggunakan teknologi sehingga terdorong untuk menggunakan teknologi yang sama (Wang \& Chou, 2014).

Perusahaan saling bersaing mengembangkan produk baik dari segi fitur maupun desain untuk menunjang semua kegiatan yang dilakukan konsumen. Penawaran keunggulan yang dimiliki oleh suatu produk membuat konsumen sadar untuk memilih produk yang sesuai dengan apa yang dibutuhkan. Saat konsumen menggunakan produk secara berulang-ulang, dapat mengakibatkan konsumen terbiasa akan produk atau layanan tersebut (Woisetschlager et al., 2011). Kebiasaan konsumen dalam menggunakan produk atau layanan tertentu dapat mempengaruhi untuk beralih pada produk atau layanan yang serupa (Rizwan, et al., 2013). Menurut Polites et al., (2012), kebiasaan merupakan urutan tindakan yang dipelajari dan telah menjadi respon otomatis terhadap situasi tertentu sehingga dapat berfungsi untuk mencapai tujuan yang ditentukan. Selanjutnya menurut Liao, et al., (2020), kebiasaan merupakan merupakan respon otomatis yang dipelajari yang dapat menghemat upaya dan waktu konsumen. Sedangkan Cheng, et al., (2018) mendefinisikan kebiasaan merupakan sejauh mana seseorang menggunakan layanan tertentu yang dilakukan secara berulang-ulang untuk menanggapi situasi tertentu. Kebiasaan dapat menciptakan niat beralih, tetapi dalam pangsa pasar yang kecil. Pangsa pasar yang kecil tidak mempengaruhi permintaan produk dalam skala besar tetapi dapat dimanfaatkan perusahaan untuk memperkenalkan produk inovatif (Rizwan et al., 2013).

Berdasarkan kajian teori dan penelitian terdahulu didapatkan kerangka konseptual untuk menjelaskan hubungan antara persepsi kegunaan (X1), pengaruh sosial (X2), dan kebiasaan (X3) terhadap niat beralih. Sehingga dapat ditentukan hubungan antara variabel bebas dengan variabel terikat sebagai berikut: persepsi kegunaan (X1) berpengaruh signifikan terhadap niat beralih pada

Pengaruh Persepsi Kegunaan, Pengaruh Sosial dan Kebiasaan Terhadap Niat Beralih Pada Pengguna Dompet 
pengguna OVO ke ShopeePay, pengaruh sosial (X2) berpengaruh signifikan terhadap niat beralih pada pengguna OVO ke ShopeePay, dan Kebiasaan berpengaruh signifikan terhadap niat beralih pada pengguna OVO ke ShopeePay. Kerangka konseptual penelitian ini ditunjukkan pada gambar 1 sebagai berikut.

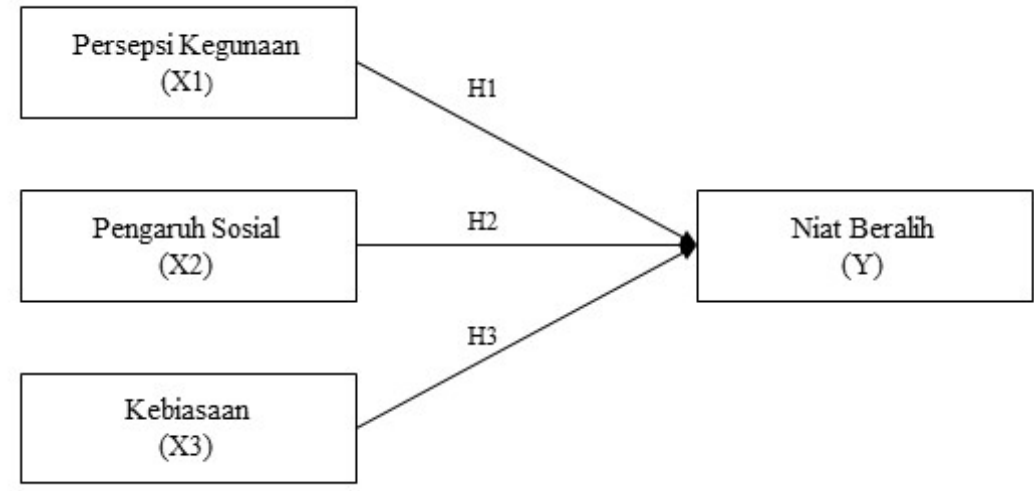

Gambar 1.

Kerangka Konseptual

Penelitian terdahulu oleh Fahmi et al., (2018) menyatakan bahwa persepsi kegunaan berpengaruh positif dan signifikan terhadap niat beralih. Sejalan pada penelitian Wirth \& Maier, (2017); dan Chen \& Keng, (2019) menunjukkan persepsi kegunaan berpengaruh signifikan terhadap niat beralih. Berbeda dengan hasil penelitian oleh Lin, (2017) yaitu persepsi kegunaan berpengaruh tidak signifikan terhadap niat beralih. Berdasarkan uraian teori dan hasil penelitian terdahulu, hipotesis penelitian ini sebagai berikut $\mathrm{H} 1$ : persepsi kegunaan berpengaruh signifikan terhadap niat beralih.

Hasil penelitian oleh Ali et al., (2020) menyatakan pengaruh sosial berpengaruh positif dan signifikan terhdap niat beralih. Sejalan dengan hasil penelitian oleh Kamolsook et al., (2019); Zhou, (2018); dan Sombultawee, (2017) menunjukkan pengaruh sosial berpengaruh signifikan terhadap niat beralih. Namun, penelitian oleh Syah et al., (2018) menyatakan pengaruh sosial berpengaruh tidak signifikan terhadap niat beralih. Berdasarkan uraian teori dan hasil penelitian terdahulu, hipotesis penelitian ini sebagai berikut H2: pengaruh sosial berpengaruh signifikan terhadap niat beralih.

Hasil penelitian oleh Rizwan et al., (2013) menyatakan kebiasaan berpengaruh positif dan dignifikan terhadap niat beralih. Berbeda dengan penelitian Minghong et al., (2020) menunjukkan bahwa kebiasaan berpengaruh negatif dan signifikan terhadap niat beralih. Sejalan dengan penelitian oleh Cheng et al., (2018) dan Lai \& Wang, (2015) yang menunjukkan bahwa kebiasaan berpengaruh negatif dan signifikan terhadap niat beralih. Sedangkan hasil penelitian Liao et al., (2020) menunjukkan tidak ada pengaruh signifikan antara kebiasaan terhadap niat beralih. Berdasarkan kajian teori dan penelitian terdahulu, hipotesis penelitian ini sebagai berikut H3: persepsi kegunaan berpengaruh signifikan terhadap niat beralih.

\section{METODE PENELITIAN}

Responden penelitian ini adalah seseorang yang berusia 20-40 tahun, sedang menggunakan OVO, dan sedang mencari informasi mengenai ShopeePay. Teknik sampling menggunakan non probability sampling dengan teknik judgemental sampling. Responden yang dibutuhkan sebesar 30 responden untuk uji validitas dan reliabilitas serta 200 responden untuk pengujian hipotesis. Pengukuran jawaban responden dengan menggunakan skala likert dengan rentan antara 1 (sangat tidak setuju) sampai 5 (sangat setuju). Pengumpulan data menggunakan angket kuisioner yang Pengaruh Persepsi Kegunaan, Pengaruh Sosial dan Kebiasaan Terhadap Niat Beralih Pada Pengguna Dompet 
didistribusikan secara online melalui Google Form yang disebar melalui sosial media seperti Instagram, Whatsapp, dan Facebook. Teknik analisis data pada penelitian ini yaitu analisis regresi linear berganda. Masing-masing pengukuran variabel diantaranya: pengukuran pada niat beralih menggunakan indikator yang dikembangkan oleh Zhou, (2018), Kamolsook et al., (2019), dan Sombultawee, (2017) pengukuran variabel persepsi kegunaan merupakan pengembangan indikator oleh Fahmi et al., (2018), Ahmed, (2017), dan Lin, (2017) yang terdiri dari 5 indikator, pengukuran variabel pengaruh sosial menggunakan indikator yang dikembangkan oleh Sombultawee, (2017), Zhou, (2018), dan Kamolsook et al., (2019) yaitu terdiri 4 indikator, dan pengukuran pada variabel kebiasaan merupakan adopsi dari indikator yang dikembangkan oleh Cheng et al., (2018), Liao et al., (2020), dan Cheng et al., (2017). Pada tabel 1 menunjukkan item-item pengukuran setiap variabel yang digunakan dalam penelitian ini.

Tabel 1.

Pengukuran Variabel Penelitian

\begin{tabular}{|c|c|c|}
\hline Variabel & Peneliti & Item \\
\hline Persepsi Kegunaan & $\begin{array}{lr}\text { Fahmi } \quad \text { et } \quad a l \\
(2018) ; \quad \text { Ahmed } \\
(2017) ; \text { Lin }(2017)\end{array}$ & 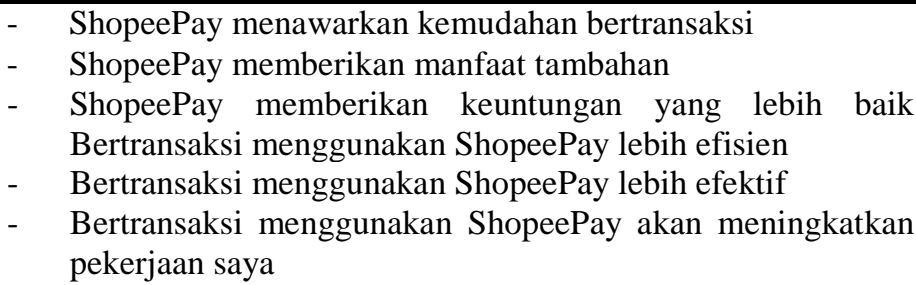 \\
\hline Pengaruh Sosial & $\begin{array}{l}\text { Sombultawee } \\
(2017) ; \text { Zhou } \\
(2017) \text {; } \\
\text { Kamolsook et al., } \\
(2019)\end{array}$ & $\begin{array}{ll}\text { - } & \text { Keluarga mempengaruhi saya menggunakan ShopeePay } \\
\text { - } & \text { Teman mempengaruhi saya menggunakan ShopeePay } \\
\text { - } & \text { Rekan kerja mempengaruhi saya menggunakan ShopeePay } \\
\text { - } & \text { Orang di sekitar saya mempengaruhi saya menggunakan } \\
& \text { ShopeePay }\end{array}$ \\
\hline Kebiasaan & $\begin{array}{l}\text { Cheng et al. } \\
\text { (2018); Liao et al. } \\
(2020) ; \text { Cheng et } \\
\text { al (2017) }\end{array}$ & $\begin{array}{l}\text { - } \quad \text { Menggunakan dompet digital tanpa berpikir panjang } \\
\text { - } \quad \text { Menggunakan dompet digital adalah hal yang wajar } \\
\text { - } \quad \text { Bertransaksi menggunakan dompet digital di merchant } \\
\text { adalah hal normal } \\
\text { - } \quad \text { Menggunakan dompet digital secara berulang-ulang } \\
\text { - } \quad \text { Menggunakan dompet digital adalah pilihan tepat bagi saya }\end{array}$ \\
\hline Niat Beralih & $\begin{array}{l}\text { Zhou (2018); } \\
\text { Kamolsook } \\
(2019) ; \\
\text { Sombultawee } \\
(2017)\end{array}$ & $\begin{array}{l}\text { - Saya mempertimbangkan untuk beralih menggunakan } \\
\text { ShopeePay } \\
\text { - Saya berencana untuk beralih menggunakan ShopeePay } \\
\text { - } \quad \text { Saya pasti beralih menggunakan ShopeePay }\end{array}$ \\
\hline
\end{tabular}

Sumber: Data diolah, 2021

\section{HASIL DAN PEMBAHASAN}

Pada uji validitas dan reabilitas penelitian ini dilakukan pada 30 responden diluar dari 200 responden penelitian ini. Berdasarkan hasil uji validitas, item-item pengukuran pada penelitian ini dinyatakan valid dengan melihat nilai colerated item-total yang menghasilkan nilai $r$ hitung $>\mathrm{r}$ tabel dan bernilai positif (Ghozali, 2018:51). Selanjutnya, $r$ tabel pada penelitian ini yaitu 0,361 menggunakan asumsi kesalahan sebesar 5\%. Sedangkan hasil pengujian reliabialitas dapat dilihat pada nilai Cronbach Alpha > 0,07, sehingga dapat dinyakan reliabel (Ghozali, 2018:46). Dalam penelitian ini seluruh item pengukuran dikatakan valid dan reliabel. Tabel 2 menunjukkan hasil uji validitas dan reabilitas.

Pengaruh Persepsi Kegunaan, Pengaruh Sosial dan Kebiasaan Terhadap Niat Beralih Pada Pengguna Dompet 
Tabel 2.

Hasil Uji Validitas dan Reliabilitas

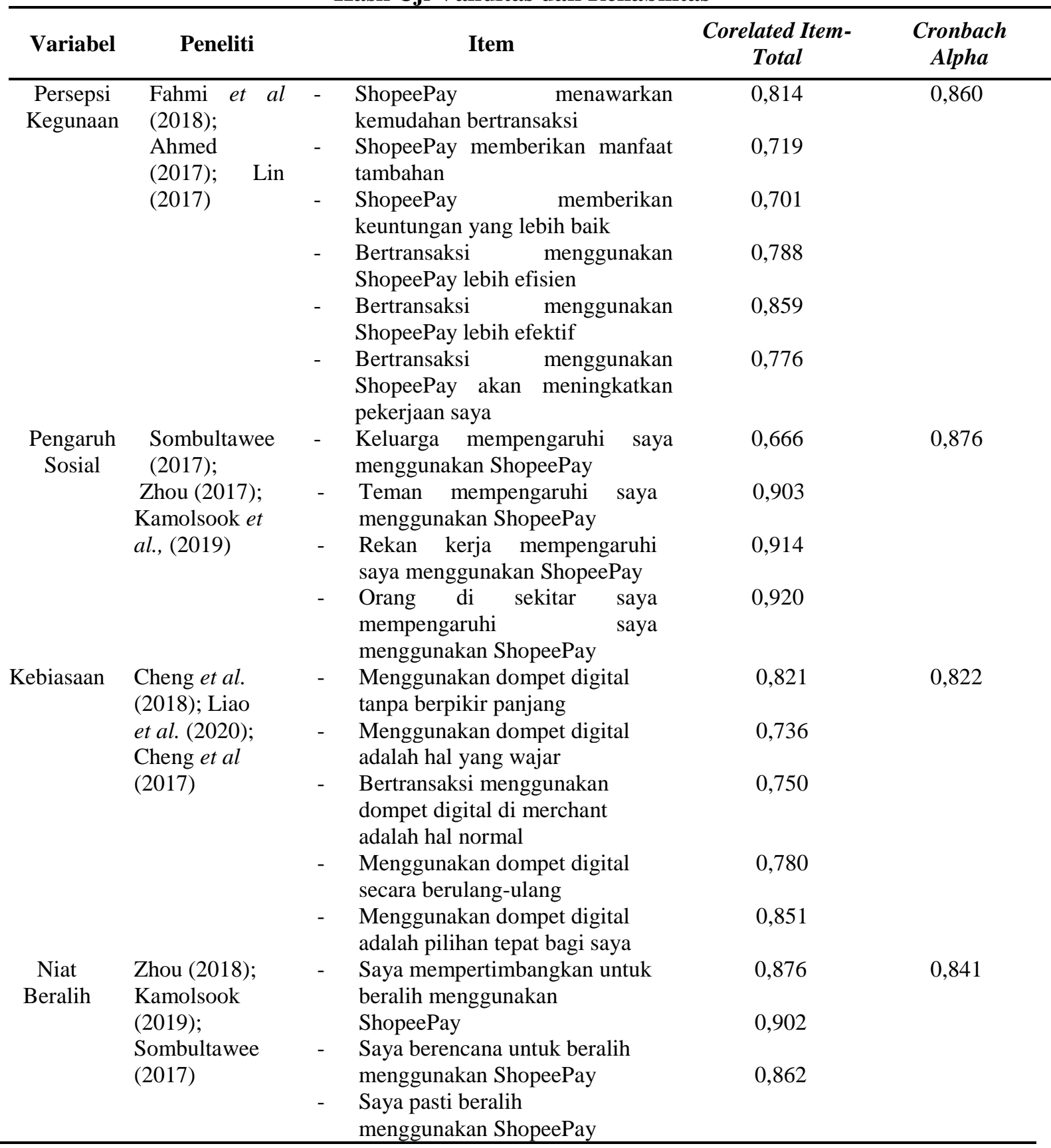

Sumber: Data diolah, 2021

Penyebaran angket dilakukan secara online kepada 200 responden yang sesuai dengan batasan yang ditentukan. Responden dari penelitian ini adalah seorang pengguna OVO dengan usia 13-50 tahun yang sedang mencari informasi mengenai ShopeePay.

Pada tabel 3 diketahui mayoritas responden penelitian ini yaitu perempuan sebesar $62 \%$ dengan rentang usia antara 20-26 tahun sebesar 84,5\%. Mayoritas pendidikan terakhir responden adalah SMA/Sederajat sebesar $67,5 \%$ dan pekerjaan sebagai mahasiswa sebesar $65 \%$. Mayoritas responden memiliki penghasilan < Rp 1.000 .000 sebesar $77 \%$.

Pengaruh Persepsi Kegunaan, Pengaruh Sosial dan Kebiasaan Terhadap Niat Beralih Pada Pengguna Dompet 
Tabel 3.

Karakteristik Responden

\begin{tabular}{|c|c|c|c|}
\hline No & Karakteristik Responden & Jumlah & Presentase \\
\hline \multirow[t]{3}{*}{1} & Jenis Kelamin & & \\
\hline & a. Laki-laki & 76 & $38 \%$ \\
\hline & b. Perenmuan & 124 & $62 \%$ \\
\hline \multirow[t]{4}{*}{2} & Usia & & \\
\hline & a. 20-26 tahun & 169 & $84,5 \%$ \\
\hline & b. 27-33 tahun & 16 & $8 \%$ \\
\hline & c. $34-40$ tahun & 15 & $7,5 \%$ \\
\hline \multirow[t]{3}{*}{3} & Status & & \\
\hline & a. Menikah & 82 & $82 \%$ \\
\hline & b. Belum menikah & 18 & $18 \%$ \\
\hline \multirow[t]{6}{*}{4} & Tingkat Pendidikan & & \\
\hline & a. SMP/Sederajat & 3 & $1,5 \%$ \\
\hline & b. SMA/Sederajat & 135 & $67,5 \%$ \\
\hline & c. Diploma & 10 & $5 \%$ \\
\hline & d. $\mathrm{S} 1$ & 49 & 24,55 \\
\hline & e. $\mathrm{S} 2$ & 3 & $1,5 \%$ \\
\hline \multirow[t]{7}{*}{5} & Pekerjaan & & \\
\hline & a. Guru & 3 & $1,5 \%$ \\
\hline & b. Karyawan Swasta & 31 & $15,5 \%$ \\
\hline & c. Pegawai Negeri & 16 & $8 \%$ \\
\hline & d. Mahasiswa & 130 & $65 \%$ \\
\hline & e. Wirausaha & 9 & $4,5 \%$ \\
\hline & f. Lainnya & 11 & $16,5 \%$ \\
\hline \multirow[t]{5}{*}{6} & Pendapatan & & \\
\hline & a. $\quad<\operatorname{Rp} 1.000 .000$ & 103 & $51,5 \%$ \\
\hline & $\begin{array}{ll}\text { b. } & \text { Rp } 1.500 .000-R p \\
& 2.500 .000\end{array}$ & 48 & $24 \%$ \\
\hline & $\begin{array}{ll}\text { c. } & \mathrm{Rp} 3.000 .000-\mathrm{Rp} \\
& 4.000 .000\end{array}$ & 22 & $11 \%$ \\
\hline & d. $>\operatorname{Rp} 4.000 .000$ & 27 & $13,5 \%$ \\
\hline
\end{tabular}

Sumber: Data diolah, 2020

Tabel 4.

Hasil Uji Normalitas

\begin{tabular}{llr}
\hline & & $\begin{array}{c}\text { Unstandarized } \\
\text { Residual }\end{array}$ \\
\hline $\mathrm{N}$ & Mean & 200 \\
Non Parameters $^{\text {a.b }}$ & Std. Deviation &, 0000000 \\
& Absolute & 1,33386012 \\
Most Extreme Differences & Positive &, 063 \\
& Negative &, 050 \\
Test Statistic & &,- 063 \\
Asymp. Sig (2-Tailed) & &, 063 \\
\hline
\end{tabular}

Sumber: Data diolah, 2020

Uji asumsi klasik pada penelitian ini menggunakan uji normalitas, multikolinearitas, dan heteroskedastisitas. Berdasarkan hasil uji normalitas pada tabel 4 dengan hasil nilai asymp. Sig (2-

Pengaruh Persepsi Kegunaan, Pengaruh Sosial dan Kebiasaan Terhadap Niat Beralih Pada Pengguna Dompet 
tailed) sebesar 0,054. Sehingga dapat disimpulkan bahwa data dalam penelitian ini berdistribusi normal karena hasil nilai signifikansi $>0,05$.

Tabel 5.

Hasil Uji Multikolinearitas

\begin{tabular}{lll}
\hline & \multicolumn{2}{c}{ Collinearity Statistic } \\
& Tolerance & VIF \\
\hline (Constant) &, 766 & \\
Persepsi Kegunaan & 732 & 1,305 \\
Pengaruh Sosial &, 724 & 1,367 \\
Kebiasaan & & 1,380 \\
\hline
\end{tabular}

Sumber: Data diolah, 2020

Pada tabel uji multikolinearitas menunjukkan nilai tolerance value dari persepsi kegunaan yaitu $0,766>0,1$, pengaruh sosial yaitu 0,732 $>0,1$, dan kebiasaan yaitu 0,724 >0,1. Begitu juga nilai VIF dari persepsi kegunaan yaitu $1,305<10$, pengaruh sosial yaitu $1,376<10$, dan kebiasaan yaitu $1,380<10$. Sehingga pada penelitian ini dapat disimpulkan tidak terjadi multikolinearitas.

Tabel 6.

Hasil Uji Heteroskedastisitas

\begin{tabular}{llrcrrr}
\hline & & $\begin{array}{c}\text { Unstandardized } \\
\text { B }\end{array}$ & $\begin{array}{c}\text { Coefficients } \\
\text { Std. Error }\end{array}$ & $\begin{array}{c}\text { Standardized } \\
\text { Coeffitients } \\
\text { Beta }\end{array}$ & t & \multicolumn{1}{c}{ Sig. } \\
\hline 1 & (Constant) &, 008 &, 048 & &, 157 &, 875 \\
& Persepsi Kegunaan &, 004 &, 002 &, 144 & 1,780 &, 077 \\
& Pengaruh Sosial &, 000 &, 002 &,- 014 &,- 171 &, 864 \\
& Kebiasaan &,- 001 &, 002 &,- 031 &,- 374 &, 709 \\
\hline
\end{tabular}

Sumber: Data diolah, 2020

Pada uji heteroskedastisitas hasil signifikansi variabel menunjukkan lebih besar dari 0,05 yaitu variabel persepsi kegunaan sebessar 0,77 , variabel pengaruh sosial sebesar 0,864 , dan variabel kebiasaan sebesar 0,709. Sehingga dalam penelitian ini menunjukkan tidak ada gejala heteroskedastisitas. Berdasarkan tiga uji asumsi klasik, enunjukkan hasil penelitian ini telah memenuhi uji normalitas, multikolinearitas, dan heteroskedastisitas sehingga data penelitian ini layak dilanjutkan ke analisis data untuk dilakukan pengujian hipotesis.

Pengujian hipotesis menggunakan uji statistik regresi linier berganda untuk mengetahui pengaruh persepsi kegunaan, pengaruh sosial, dan kebiasaan terhadap niat beralih pengguna OVO ke ShopeePay. Tabel 3 merupakan hasil analisis regresi linear berganda.

Tabel 3.

Hasil Analisis Regresi Linier Berganda

\begin{tabular}{llccccc}
\hline & & $\begin{array}{c}\text { Unstandardized } \\
\text { B }\end{array}$ & $\begin{array}{c}\text { Coefficients } \\
\text { Std. Error }\end{array}$ & $\begin{array}{c}\text { Standardized } \\
\text { Coeffitients } \\
\text { Beta }\end{array}$ & t & Sig. \\
\hline 1 & (Constant) & 3,842 &, 912 & & 4,215 &, 000 \\
& Persepsi Kegunaan &, 121 &, 037 &, 206 & 3,245 &, 001 \\
& Pengaruh Sosial &, 245 &, 038 &, 416 & 6,418 &, 000 \\
& Kebiasaan &, 082 &, 034 &, 158 & 2,424 &, 016 \\
\hline
\end{tabular}

Sumber: Data diolah, 2020

Pada tabel 5 diketahui hasil uji regresi linier berganda yang diperoleh dari persamaan linier berganda $\mathrm{Y}=3,842+0,121 \mathrm{X} 1+0,245 \mathrm{X} 2+0,082 \mathrm{X} 3$. Berdasarkan persamaan tersebut maka nilai Pengaruh Persepsi Kegunaan, Pengaruh Sosial dan Kebiasaan Terhadap Niat Beralih Pada Pengguna Dompet 
konstanta $(\alpha)$ sebesar 3,842 menunjukkan bahwa persepsi kegunaan, pengaruh sosial dan kebiasaan sama dengan 0 maka besarnya niat beralih sebesar 3,444. Nilai koefisien pada variabel persepsi kegunaan yaitu 0,121. Artinya, apabila persepsi kegunaan ShopeePay semakin besar, maka niat responden pengguna OVO untuk beralih ke ShopeePay semakin meningkat. Selanjutnya, nilai koefisien pada variabel pengaruh sosial sebesar 0,245. Artinya, apabila semakin besar pengaruh orangorang di lingkungan sosial responden pengguna OVO maka semakin besar niat untuk beralih menggunakan ShopeePay. Pada variabel kebiasaan menunjukkan nilai koefisien sebesar 0,082. Artinya, apabila semakin besar kebiasaan responden pengguna dompet digital, maka niat untuk beralih menggunakan dompet digital lain yang memiliki keunggulan yang berbeda akan semakin besar.

Berdasarkan hasil analisi regresi linear berganda pada tabel 5, diketahui bahwa t hitung persepsi kegunaan sebesar 3,245 dengan nilai signifikansi 0,001. Apabila nilai signifikansi lebih kecil dari 0,05 , dapat disimpulkan bahwa $\mathrm{H}_{0}$ ditolak dan $\mathrm{H}_{\mathrm{a}}$ diterima. Sehingga dapat dinyatakan bahwa terdapat pengaruh antara persepsi kegunaan terhadap niat beralih untuk menggunakan ShopeePay. Kemudian variabel pengaruh sosial menunjukkan nilai t hitung sebesar 6,418 dengan nilai signifikansi $0,000<0,05$, sehingga $\mathrm{H}_{0}$ ditolak dan $\mathrm{H}_{\mathrm{a}}$ diterima. Hal ini dapat disimpulkan bahwa terdapat pengaruh antara pengaruh sosial dengan niat beralih untuk menggunakan ShopeePay. Selanjutnya, variabel kebiasaan menunjukkan nilai t hitung sebesar 2.424 dengan nilai signifikansi 0,016 yang lebih kecil dari 0,05 , maka $\mathrm{H}_{0}$ ditolak dan $\mathrm{H}_{\mathrm{a}}$ diterima. Sehingga dapat disimpulkan bahwa terdapat pengaruh antara kebiasaan terhadap niat beralih untuk menggunakan ShopeePay.

Tabel 5.

Koefisien Determinasi

\begin{tabular}{|c|c|c|c|c|}
\hline Model & $\mathbf{R}$ & R Square & $\begin{array}{c}\text { Adjusted R } \\
\text { Square }\end{array}$ & $\begin{array}{l}\text { Std. Error of } \\
\text { the Extimate }\end{array}$ \\
\hline 1 &, $631^{\mathrm{a}}$ & ,398 & ,388 & 1,344 \\
\hline
\end{tabular}

Pengaruh masing-masing variabel independen terhadap variabel dependen dapat dilihat pada nilai $R$ Square sebesar 0,398, dimana dari didapatkan hasil terdapat kontribusi variabel persepsi kegunaan, pengaruh sosial, dan kebiasaan terhadap niat beralih pada pengguna OVO ke ShopeePay sebesar $39,8 \%$. Sedangkan sebesar $60,2 \%$ yang mempengaruhi niat beralih yaitu variabel lain diluar variabel pada penelitian ini.

Berdasarkan hasil uji yang telah dilakukan oleh peneliti dapat disimpulkan bahwa persepsi kegunaan berpengaruh signifikan terhadap niat beralih. Hasil tersebut mendukung hipotesis pertama yaitu "persepsi kegunaan berpengaruh signifikan terhadap niat beralih" pada pengguna OVO ke ShopePay. Hasil dari penelitian ini mendukung pernyataan (Fahmi et al., 2018; Wirth \& Maier, 2017; dan Chen \& Keng, 2019) bahwa persepsi kegunaan berpengaruh signifikan terhadap niat beralih. Namun hasil penelitian menolak penelitian dari (Lin, 2017) yang menyatakan bahwa persepsi kegunaan berpengaruh tidak signifikan terhadap niat beralih. Adanya pengaruh signifikan antara persepsi kegunaan terhadap niat beralih dikarenakan dengan menggunakan ShopeePay dapat meningkatkan kinerja penggunanya dengan bisa bertransaksi dan berbelanja produk secara online dalam satu aplikasi. Mereka menganggap bahwa inovasi akan fitur-fitur yang dilakukan oleh ShopeePay sangat memudahkan untuk bertransaksi yang berbeda dari dompet digital sebelumnya seperti tiket kereta dan pesawat, tiket bioskop, tiket webinar, serta tabungan emas yang telah bekerjasama dengan pegadaian. Kemudian dari hasil karakteristik responden, penelitian didominasi oleh perempuan dengan rentang usia 20 -26 tahun yang memiliki status sebagai mahasiswa. Hal ini dikarenakan perempuan menyukai keuntungan yang didapat saat berbelanja online seperti cashback dan gratis ongkir yang ditawarkan ShopeePay saat melakukan transaksi menggunakan ShopeePay.

Pengaruh Persepsi Kegunaan, Pengaruh Sosial dan Kebiasaan Terhadap Niat Beralih Pada Pengguna Dompet 
Perempuan dengan status mahasiswa lebih banyak memiliki waktu luang sehingga menyukai fiturfitur inovasi dari dompet digital serta banyaknya merchant yang telah bekerja sama dengan ShopeePay. Pengguna dompet digital biasanya memperhatikan merchant offline dimana dapat dilakukan transaksi dengan menggunakan ShopeePay dan pada merchant online dimana dapat dilakukan transaksi pada website atau aplikasi dengan menggunakan ShopeePay. Ketika pengguna mendapatkan informasi dan percaya bahwa menggunakan ShopeePay dapat meningkatkan kinerja karena dapat melakukan berbagai transaksi dalam satu aplikasi akan menciptakan niat untuk beralih.

Berdasarkan hasil analisis yang didapatkan peneliti diketahui bahwa pengaruh sosial berpengaruh signifikan terhadap niat beralih. Hasil tersebut mendukung hipotesis kedua yaitu "pengaruh sosial berpengaruh signifikan terhadap niat beralih pada pengguna OVO ke ShopeePay. Penelitian ini memperkuat beberapa penelitian terdahulu oleh (Ali et al., 2020; Kamolsook et al., 2019; Zhou, 2018; dan Sombultawee, 2017) yang menyatakan terdapat pengaruh signifikan antara pengaruh sosial terhadap niat beralih. Namun penelitian ini menolak penelitian oleh (Syah et al., 2018), menunjukkan bahwa pengaruh sosial berpengaruh tidak signifikan terhadap niat beralih. Adanya pengaruh signifikan pengaruh sosial terhadap niat beralih dikarenakan ketika seseorang tertarik dengan brand dompet digital lain, mereka akan mencari informasi melalui berbagai sumber salah satunya dengan bertanya dan meminta rekomendasi dari orang sekitarnya. Apabila seseorang mengatakan hal-hal yang positif mengenai ShopeePay kemudian merekomendasikannya kepada orang lain akan menambah ketertarikan pada ShopeePay. Jika dikaitkan dengan karakteristik responden, penelitian ini didominasi oleh perempuan dengan rentan usia 20-26 tahun yang memiliki status sebagai mahasiswa. Hal ini dikarenakan dalam rentan usia 20-26 tahun masih memiliki antusias untuk banyak mencari layanan yang sedang tren dan berbeda dari pesaingnya, sehingga mereka akan mudah bergeser menggunakan merek lain. Selain itu, dalam rentang usia 20-26 tahun dengan status sebagai mahasiswa terjadi pergeseran ketergantungan dalam pengambilan keputusan dari orang tua ke lingkungan sosial seperti teman dan rekan kerja sehingga mereka akan memperhatikan pendapat dan evaluasi orang-orang di sekitarnya terhadap ShopeePay.

Penelitian ini menyatakan kebiasaan berpengaruh signifikan terhadap niat beralih. Hasil penelitain ini memperkuat penelitian oleh (Rizwan et al., 2013) yang menunjukkan bahwa kebiasaan mempengaruhi secara signifikan terhadap niat beralih. Namun hasil penelitian ini menolak penelitian dari (Liao et al., 2020) yang menyatakan bahwa kebiasaan berpengaruh tidak signifikan terhadap niat beralih. Kebiasaan dalam menggunakan dompet digital menciptakan niat beralih pada layanan sejenis yang memiliki inovasi yang berbeda. Persamaan garis besar dalam penggunaannya membuat pengguna tidak perlu mempelajarinya mulai dari awal, tetapi menyesuaikan terhadap fitur-fitur baru yang dimiliki oleh ShopeePay. Berdasarkan hasil jawaban responden terhadap angket yang disebarkan, mayoritas responden menyatakan bahwa bertransaksi menggunakan dompet digital saat ini merupakan hal yang wajar. Jika dikaitkan dengan karakteristik reponden, penelitian ini didominasi oleh responden perempuan dengan rentan usia 20-26 tahun yang memiliki status sebagai mahasiswa. Hal ini dikarenakan penggunaan dompet digital biasa dijumpai di kalangan mahasiswa. Mahasiswa menyukai hal yang efisien yaitu dengan menggunakan smartphone bisa digunakan untuk bertransaksi. Selain itu, dalam rentan usia 20-26 tahun masih memiliki antusias untuk mencoba inovasi teknologi yang sebelumnya digunakan dengan brand baru yang dirasa akan lebih menguntungkan. Maka hal ini menunjukkan kebiasaan yang tinggi terhadap dompet digital maka semakin tinggi niat beralih pengguna pada layanan sejenis dengan inovasi yang baru dan berbeda

Pengaruh Persepsi Kegunaan, Pengaruh Sosial dan Kebiasaan Terhadap Niat Beralih Pada Pengguna Dompet 


\section{SIMPULAN DAN SARAN}

Berdasarkan uraian hasil penelitian, kesimpulan penelitian ini adalah variabel persepsi kegunaan berpengaruh signifikan terhadap niat beralih pengguna OVO ke ShopeePay. Lebih lanjut, variabel pengaruh sosial berpengaruh signifikan terhadap niat beralih pengguna OVO ke ShopeePay. Kemudian, dari hasil penelitian menunjukkan variabel kebiasaan berpengaruh signifikan terhadap niat beralih pengguna OVO ke ShopeePay.

Berdasarkan uraian hasil dan pembahasan, saran peneliti untuk penelitian akan datang yaitu menggunakan variabel bebas lainnya yang berpengaruh terhadap niat beralih seperti kelompok referensi, keunggulan relatif, dan sebagainya. Kemudian untuk perusahaan OVO diharapkan untuk dapat meningkatkan dan melakukan inovasi terhadap fitur-fitur yang diperlukan saat ini misalnya pembayaran tiket bioskop virtual, tiket konser virtual, dan lain sebagainya. Selanjutnya, OVO bisa menambah kerjasama dengan merchant seperti minimarket yang mudah dijangkau meskipun rumah pengguna tidak berada di pusat kota. Selain itu, OVO dapat menekankan kebaruan terhadap fitur yang dimilikinya sehingga pengguna merasa diuntungkan dengan menggunakan OVO dalam bertransaksi sehari-hari. Berdasarkan permasalahan tersebut, pihak OVO dapat merumuskan strategi untuk menekan niat beralih penggunanya sekaligus meningkatkan kualitas dan kebaruan sehingga dapat mempertahankan pengguna lama dan dapat menarik pengguna baru OVO.

\section{REFERENSI}

Ahmed, C. M. S. O. A.-K. Z. U. (2017). Building a Comprehensive Model to Investigate Factors behind Switching Intention of High Technology Products. Emerald Insight, 26(2). https://doi.org/http://dx.doi.org/10.1108/JPBM-06-2015-0915

Bansal, H. S., Taylor, S. F., \& James, Y. S. (2005). "Migrating" to new service providers: Toward a unifying framework of consumers' switching behaviors. Journal of the Academy of Marketing Science, 33(1), 96115. https://doi.org/10.1177/0092070304267928

Chang, Y. (2017). An empirical investigation of organizations ' switching intention to cloud enterprise resource planning: a cost-benefit perspective. Information Development. https://doi.org/10.1177/0266666917743287

Chen, Y. H., \& Keng, C. J. (2019). Utilizing the Push-Pull-Mooring-Habit framework to explore users' intention to switch from offline to online real-person English learning platform. Internet Research, 29(1), 167-193. https://doi.org/10.1108/IntR-09-2017-0343

Cheng, S., Lee, S. J., \& Choi, B. (2018). An empirical investigation of users' voluntary switching intention for mobile personal cloud storage services based on the push-pull-mooring framework. Computers in Human Behavior, 92, 198-215. https://doi.org/10.1016/j.chb.2018.10.035

Cheng, X., Fu, S., \& Yin, G. (2017). Does subsidy work? An investigation of post-adoption switching on carhailing apps. Journal of Electronic Commerce Research, 18(4), 317-329.

Fahmi, S, Noermijati, Rohman, F., \& Sunaryo. (2018). Factors Affecting Indonesian Consumers to Switch, Using Mobile Banking and Internet Banking Service. KnE Social Sciences, 3(10), 1236-1248. https://doi.org/10.18502/kss.v3i10.3465

Fahmi, Syaifuddin, \& Rohman, F. (2018). Factors Affecting Indonesian Consumers to Switch , Using Mobile Banking and Internet Banking Service. The 2018 International Conference of Organizational Innovation, KnE Social Sciences, 2018, 1236-1248. https://doi.org/10.18502/kss.v3i10.3465

Ghozali, I. (2018). Aplikasi Analisis Multivariate dengan Program IBM SPSS 25 (Sembilan). Semarang: Badan Penerbit Universitas Diponegoro.

iprice.co.id. (2020). E Wallet Lokal Masih Mendominasi Q2 2019-2020. Retrieved November 5, 2020, from www.iprice.co.id website: https://iprice.co.id/trend/insights/top-e-wallet-di-indonesia-2020/

Jezy, B., \& Papalapu, N. (2015). the Impact of Push, Pull, and Mooring To Customer Switching Behavior (Case Study on Customer Indovision in Manado) Pengaruh Push, Pull, Dan Mooring Terhadap Perilaku Beralih Konsumen (Study Kasus Pada Konsumen Indovision Manado). Jurnal Berkala Ilmiah Efisiensi, 15(04), 458-469. Retrieved from http://download.portalgaruda.org/article.php?article=378377\&val=5795\&title=THE IMPACT OF PUSH, PULL, AND MOORING TO CUSTOMER SWITCHING BEHAVIOR (CASE STUDY ON CUSTOMER

Pengaruh Persepsi Kegunaan, Pengaruh Sosial dan Kebiasaan Terhadap Niat Beralih Pada Pengguna Dompet Digital, 
INDOVISION IN MANADO)

Kamolsook, A., Badir, Y. F., \& Frank, B. (2019). Consumers'switching to disruptive technology products: The roles of comparative economic value and technology type. Technological Forecasting and Social Change, 140(May 2017), 328-340. https://doi.org/10.1016/j.techfore.2018.12.023

katadata.com. (2020). Mana yang Lebih Favorit, E-Money atau E-Wallet. Retrieved from ww.katadata.com website: https://katadata.co.id/muhammadridhoi/analisisdata/5f97c41b49705/mana-yang-paling-favorit-emoney-atau-e-wallet

Keaveney, S. M. (1995). Customer Switching Behaviour in Service Industries: An Explotary Study. Journal of Marketing, 59(April), 71-82. https://doi.org/https://doi.org/10.1177\%2F002224299505900206

Kompas.com. (2020). Studi: 68 Persen Pengguna Dompet Digital adalah Milenial. Retrieved November 20, 2020, from www.kompas.com website: https://money.kompas.com/read/2020/02/12/131300826/studi--68persen-pengguna-dompet-digital-adalah-milenial

Liao, J., Li, M., Wei, H., \& Tong, Z. (2020). Antecedents of smartphone brand switching: a push-pull-mooring framework. Asia Pacific Journal of Marketing and Logistics. https://doi.org/10.1108/APJML-06-20200397

Lin, C. (2017). Why not be "smarter"? Examining the factors that influence the behavioral intentions of nonsmartphone users. Emerald Insight, 117(1), 2-31. https://doi.org/10.1108/IMDS-07-2015-0319

Polites, G. L., Williams, C. K., Karahanna, E., \& Seligman, L. (2012). A Theoretical Framework for Consumer E-Satisfaction and Site Stickiness: An Evaluation in the Context of Online Hotel Reservations. Journal of Organizational Computing and Electronic Commerce, 22(1), 1-37. https://doi.org/10.1080/10919392.2012.642242

Rizwan, M., Hayat, R., \& Ali, M. (2013). Antecedents of Customer Switching Intentions: A case study of Nokia Mobile Phones' users. Journal of Public Administration and Governance, 3(3), 375. https://doi.org/10.5296/jpag.v3i3.6227

Rumengan, R. L. (2015). The Influence of Switching Cost, Time and Variety Seeking on Consumer Switching Intention (a Study on Kiosk and Minimarket in .... Jurnal Berkala Ilmiah Efisiensi, 15(05), 873-883. Retrieved from https://ejournal.unsrat.ac.id/index.php/jbie/article/view/10505

Sombultawee, K. (2017). Mobile Commerce Switching Intentions in Thai Consumers. Mediterranean Journal of Social Sciences, 8(6), 123-134. https://doi.org/10.1515/mjss-2017-0049

Sun, H., \& Zhang, P. (2006). The role of moderating factors in user technology acceptance. International Journal of Human Computer Studies, 64, 53-78. https://doi.org/10.1016/j.ijhcs.2005.04.013

Syah, S. R. S. R., Ibrahim, I., \& Sufardi, S. (2018). Switching Behavior Nasabah Bank: Tinjauan Empiris Teori Keperilakuan Di Kota Makassar. Jurnal Ad'ministrare, 5(2), 113. https://doi.org/10.26858/ja.v5i2.7973

Wang, E. S., \& Chou, N. P. (2014). Consumer Characteristics, Social Influence, and System Factors on Online Group-Buying Repurchasing Intention Graduate institute of bio-industry management. Journal of Electronic Commerce Research, 15(2), 119-132.

Wartaekonomi.com. (2019). GoPay atau OVO yang Paling Banyak Digunakan di Indonesia? Retrieved November 5, 2020, from www.wartaekonomi.co.id https://www.wartaekonomi.co.id/read239179/gopay-atau-ovo-yang-paling-banyak-digunakan-diindonesia.html

Wartaekonomi.com. (2020a). Ada Apa dengan Generasi Milenial Pengguna E-Payment? Retrieved November 5, 2020, from www.wartaekonomi.co.id website: https://www.wartaekonomi.co.id/read269532/ada-apadengan-generasi-milenial-pengguna-e-payment

Wartaekonomi.com. (2020b). Bikin Melongo, OVO hingga GoPay Didepak ShopeePay. Retrieved November 5, 2020, from www.wartaekonomi.co.id website: https:/www.wartaekonomi.co.id/read300676/bikinmelongo-ovo-hingga-gopay-didepak-shopeepay

Wirth, J., \& Maier, C. (2017). Why individuals switch to using mobile payment: A migration-theoretic, empirical study. AMCIS 2017 - America's Conference on Information Systems: A Tradition of Innovation, 2017-Augus, 1-10.

Woisetschläger, D. M., Lentz, P., \& Evanschitzky, H. (2011). How habits, social ties, and economic switching barriers affect customer loyalty in contractual service settings. Journal of Business Research, 64(8), 800808. https://doi.org/10.1016/j.jbusres.2010.10.007

Zhou, T. (2018). Examining users' switch from online banking to mobile banking. International Journal of Networking and Virtual Organisations, 18(1), 51-66. https://doi.org/10.1504/IJNVO.2018.090675 